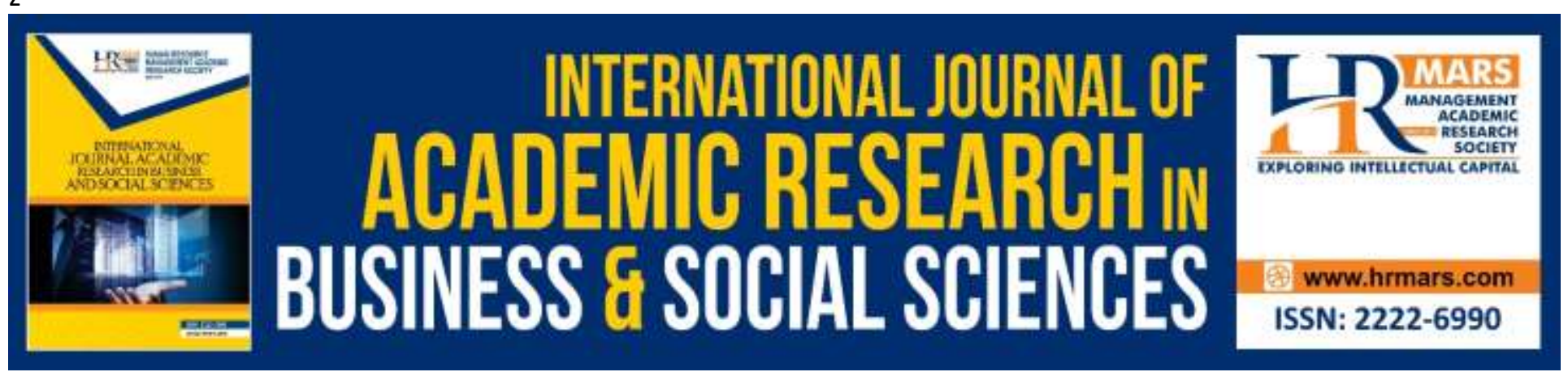

\title{
Validity and Reliability of the Malay Social Traits Instrument Using Rasch Measurement Model
}

Alizah Lambri, Zamri Mahamod, Norazimah Zakaria, Hasrina Baharum, Zaliza Hanapi

To Link this Article: http://dx.doi.org/10.6007/IJARBSS/v9-i7/6111

DOI: $10.6007 /$ IJARBSS/v9-i7/6111

Received: 07 May 2019, Revised: 19 June 2019, Accepted: 04 July 2019

Published Online: 25 July 2019

In-Text Citation: (Lambri, Mahamod, Zakaria, Baharum, \& Hanapi, 2019)

To Cite this Article: Lambri, A., Mahamod, Z., Zakaria, N., Baharum, H., \& Hanapi, Z. (2019). Validity and Reliability of the Malay Social Traits Instrument Using Rasch Measurement Model. International Journal of Academic Research in Business and Social Sciences, 9(7), 225-232.

Copyright: (C) 2019 The Author(s)

Published by Human Resource Management Academic Research Society (www.hrmars.com)

This article is published under the Creative Commons Attribution (CC BY 4.0) license. Anyone may reproduce, distribute, translate and create derivative works of this article (for both commercial and non-commercial purposes), subject to full attribution to the original publication and authors. The full terms of this license may be seen

at: http://creativecommons.org/licences/by/4.0/legalcode

Vol. 9, No. 7, 2019, Pg. 225 - 232

http://hrmars.com/index.php/pages/detail/IJARBSS

JOURNAL HOMEPAGE

Full Terms \& Conditions of access and use can be found at http://hrmars.com/index.php/pages/detail/publication-ethics 


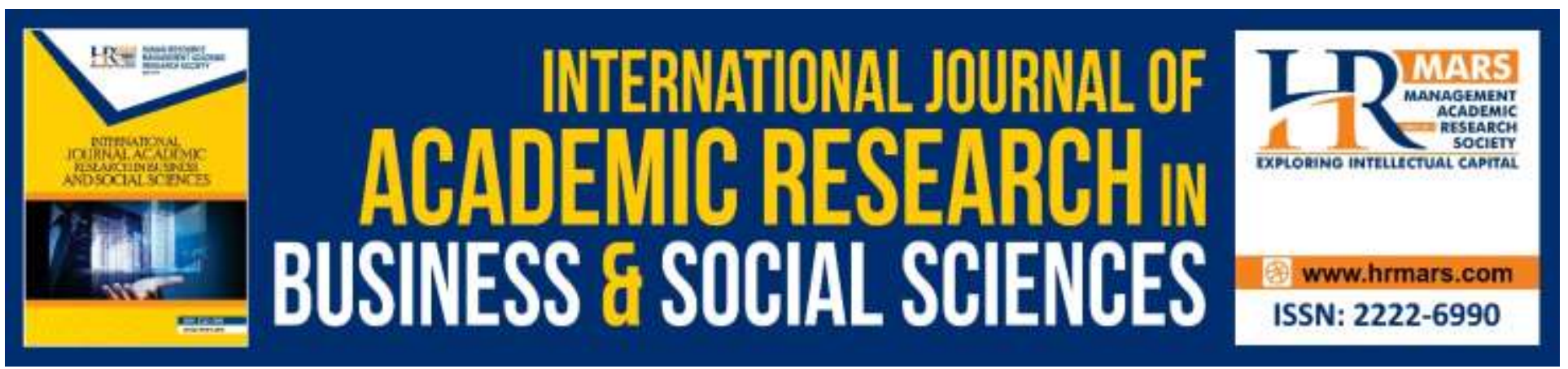

\title{
Validity and Reliability of the Malay Social Traits Instrument Using Rasch Measurement Model
}

\author{
Alizah Lambri, Zamri Mahamod, Norazimah Zakaria, Hasrina \\ Baharum, Zaliza Hanapi
}

Faculty of Languages and Communication, Universiti Pendidikan Sultan Idris Perak, Malaysia

Email: alizah@fbk.upsi.edu.my

\begin{abstract}
The Malay Social Traits questionnaire has been developed to measure the core social traits that is practiced by Malay students in Public Universities for the formation of good manners and morals based on the core of Malay social traits introduced by Hashim Musa. However, of the 26 components of the social traits that were introduced, only four core social traits were focused on this study, namely the core of religion, the core of knowledge, the core of the education and the core of values. A survey was conducted on 500 Malay students in education field at five public universities. Of the 500 questionnaires distributed, only 268 were returned for analysis. The validity and reliability of the Malay Social Traits questionnaire was measured by the Rasch Measurement Model. The findings from the Winstep analysis show validity, item reliability index and respondent reliability index are relatively high. The implication of this study is to produce an instrument that can measure and identify the Malay social traits that forms manners and morals among students at the public universities.

Keywords: Validity of Questionnaire, Reliability of Instrument, Malay Social Traits, Malay Students, Rasch Measurement Model
\end{abstract}

\section{Introduction}

Various issues related to the lack of students for the teachers are often heard at school or in higher education, till there are students who are willing to kill lecturers, only because of dissatisfaction with the lecturer. Issues like these are serious issues and it is necessary to think of measures to address similar cases from continuing. Among the causes of such cases are the lack of a student's proficiency towards their teachers. Therefore, this study was conducted to see how far the Malay social traits that was introduced by Musa (2008) is able to be practiced by the Malay students in shaping the personality and identity of the students, thus forming themselves to be civilized and ethical students, especially towards their lecturers at the Public Universities. The aspiration of the nation to produce superior human capital, and a noble character can be achieved with the creation of the students, especially students in institutions of higher learning who are virtuous and have a healthy mind and 
good sense of well-being. This is because good hearts and minds will reflect the politeness and wisdom of an individual in thinking and action.

Thus, a set of questionnaires was developed as a research instrument for the purpose of obtaining information related to the social traits that are the core of ethics and morality of Malay students in the Public Universities. This set of questionnaire focuses only on the four aspects of the social traits, namely the core of religion, the core of education, the core of knowledge and the value. To ensure that the built-in instrument can accurately measure what to measure and have high levels of validity and reliability, then the validity and reliability of the instrument being designed should be carried out. According to Rosseni et al. (2009), the study of validity and reliability of the instrument is essential to maintain the accuracy of the questionnaire from being exposed to disability. The validity and reliability of a measuring tool or instrument can be determined by using the Rasch Model founded by Rasch in 1960. According to Baker and Kim (2004), Rasch Model is one of the models of Item Response Thepry model that is commonly for the purpose of analyzing the validity and reliability of the items to be measured.

\section{Research Objectives}

Specifically, the objectives of this study are:

1. Identify the reliability of items and respondents of the Malay social traits instrument in the forming of manners and morals of Malay students in Public Universities.

2. Identify the isolation of items and respondents of the Malay social traits in forming the manners and morality of Malay students at the Public Universities.

3. Examine the polarity of the item which measures the construct of the Malay social traits instrument in forming manners and morals of the Malay students in the Public Universities based on the value of PTMEA CORR.

\section{Methodology}

\section{Location and Respondents}

This study is a survey conducted on 500 Malay students in education field at five Public Universities. Of the 500 questionnaires distributed, only 268 were returned for analysis.

\section{Instrument}

The research instrument consists of 2 parts, namely Part A, demographics, while Part B consists of 3 sub categories namely, (a) lecturer's thoughts on lecturers; (b) the core of social traits that becomes the student's practice (c) the influence of the social traits in forming a good relationship between students and lecturers. The research instrument was tested on validity and reliability through the Rasch Measurement Model analysis.

\section{Research Findings}

$1^{\text {st }}$ Objective: Identify the reliability of items and respondents of the Malay social traits instrument in the forming of manners and morals of Malay students in Public Universities. 
INTERNATIONAL JOURNAL OF ACADEMIC RESEARCH IN BUSINESS AND SOCIAL SCIENCES Vol. 9, No. 7, July, 2019, E-ISSN: 2222-6990 @ 2019 HRMARS

Table 1 shows a summary of statistics that measures 268 respondents and 69 Likert scaled items. The individual reliability index is 0.94 and the item reliability index is 0.95 . The items have high reliability (Bond \& Fox 2007). Individual and item reliability can demonstrate the extent to which the item's compatibility to the Rasch Model (confirm to fit) and the respondents separation index and items.

Table 1: Analysis of reliability and isolation index for the study of the Malay social traits in forming values and moral of students at the Public Universities

INPUT: 268 PERSON 69 ITEM REPORTED: 268 PERSON 69 ITEM 5 CATS WINSTEPS 3.73

SUMMARY OF 268 MEASURED PERSON

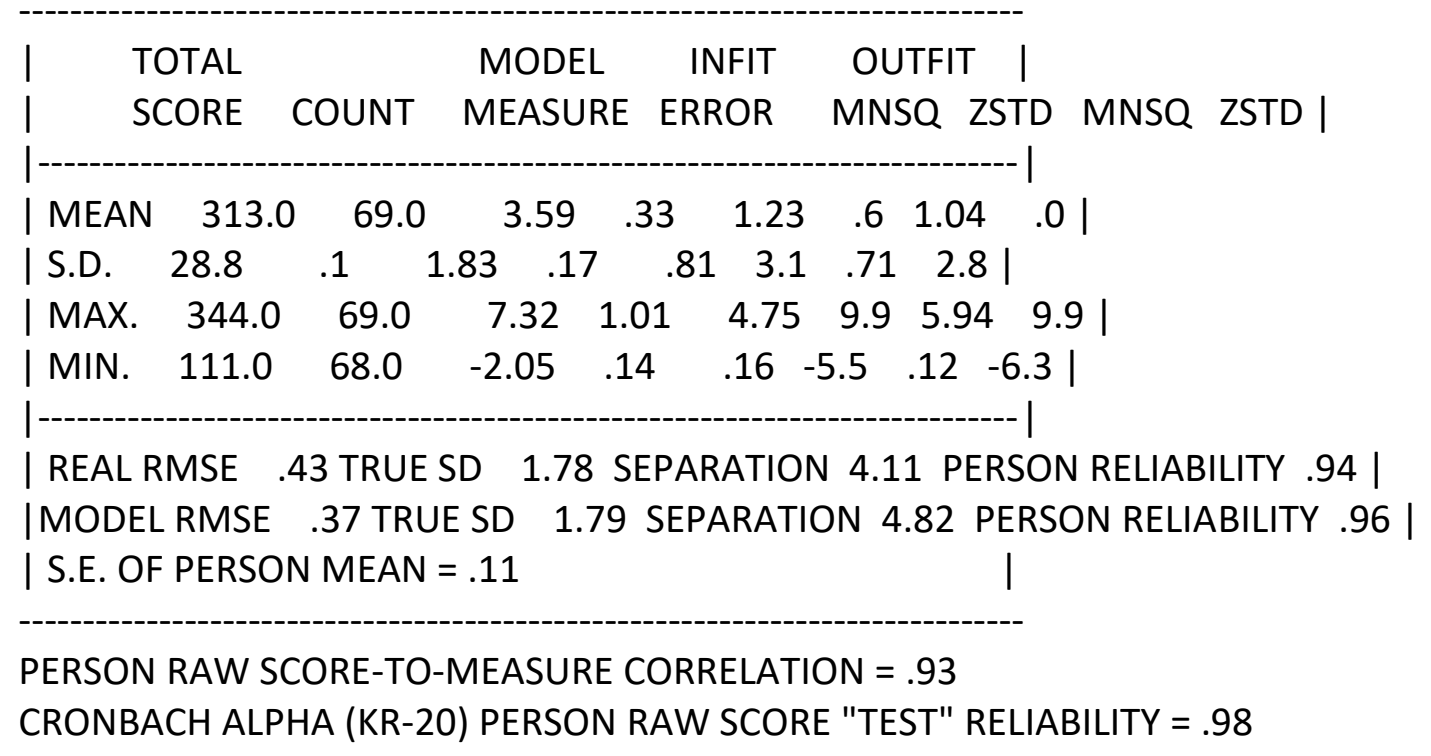

SUMMARY OF 69 MEASURED ITEM

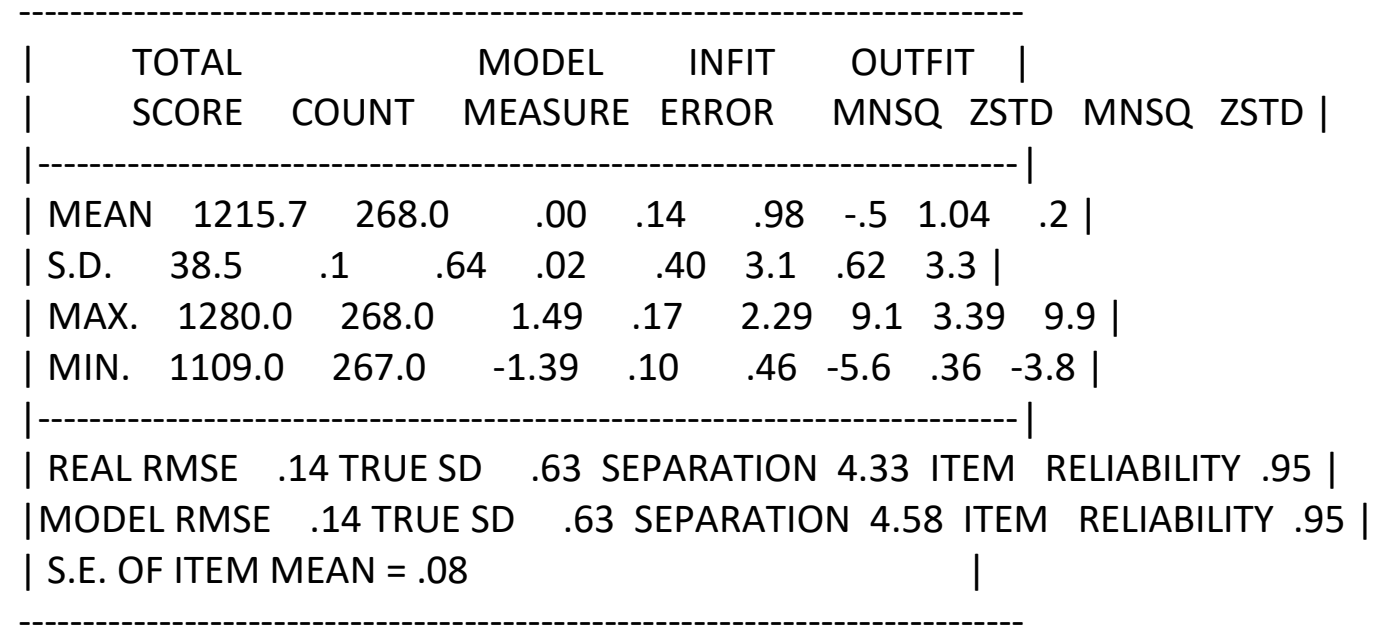


INTERNATIONAL JOURNAL OF ACADEMIC RESEARCH IN BUSINESS AND SOCIAL SCIENCES

Vol. 9, No. 7, July, 2019, E-ISSN: 2222-6990 @ 2019 HRMARS

UMEAN $=.0000$ USCALE $=1.0000$

ITEM RAW SCORE-TO-MEASURE CORRELATION = -.99

18491 DATA POINTS. LOG-LIKELIHOOD CHI-SQUARE: 20770.50 with 18152 d.f. $p=.0000$

Global Root-Mean-Square Residual (excluding extreme scores): .4713

$2^{\text {nd }}$ Objective: Isolation of Items and Respondents

Table 1 shows the isolation index for 69 items that can be divided into four (4.33) group items at two SEs, where there are four levels of different item consent in this study. This value indicates that the items have formed a well - distributed variable and the position of the item at the logit scale is of high reliability. Table 1 shows the value of separation of respondents for 268 students can be divided into four groups (4.11) of the ability of respondents as measured in the Malay social traits items to form the value and moral of public university students.

Table 2 also shows item reliability index for the nine constructs of this research instrument. According to Bond and Fox (2007), the reliability value of more than 0.8 is a strong acceptable value, while the value between $0.6-0.8$ is less accepted and less than 0.6 is not accepted. Therefore, the reliability of constructs for the influence of values 0.88 is accepted. However, items in this construct need to be viewed again as items may not measure what should be measured for the constructs.

Table 2 Reliability analysis and isolation index for each of the constructs of the Malay social traits in developing the values and morality of public university students

\begin{tabular}{lcccc}
\hline No & Construct & Total item & \multicolumn{2}{c}{ Reliability } \\
& & & Item & Isolation \\
\hline 1 & Students' Thinking & 15 & 0.97 & 5.29 \\
2 & Religious core & 9 & 0.99 & 11.24 \\
3 & Education core & 10 & 0.99 & 13.51 \\
4 & Knowledge core & 12 & 1.00 & 14.78 \\
5 & Value core & 8 & 0.99 & 13.57 \\
6 & Religious influence & 5 & 1.00 & 16.60 \\
7 & Education influence & 8 & 1.00 & 14.15 \\
8 & Knowledge influence & 9 & 0.93 & 3.55 \\
9 & Value influence & 11 & 0.88 & 2.75 \\
\hline
\end{tabular}

Linacre (2005), Fox and Jones (1998) stated that the isolation value of the item and the respondent more than the value of two is considered good and acceptable. Values less than two are weak. Table 2 shows the index of item isolation for value construct is the lowest, which is 2.75 . But the value is still high, which is surpassing the value of two. Therefore, it is necessary to re-view the suitability of the item for the construct and the respondent who responds to reinforce the value of the construct. 
INTERNATIONAL JOURNAL OF ACADEMIC RESEARCH IN BUSINESS AND SOCIAL SCIENCES

Vol. 9, No. 7, July, 2019, E-ISSN: 2222-6990 ¿ 2019 HRMARS

\section{$3^{\text {rd }}$ Objective: Testing Item Polarity}

Table 3 shows items that have positive and negative values. There is one item with negative value from the value construct (VC) and there are four items less than .30. namely two items from education construct (EC) and two more items from El (Educational Influence) construct.

Table 3. Value PTMEA item

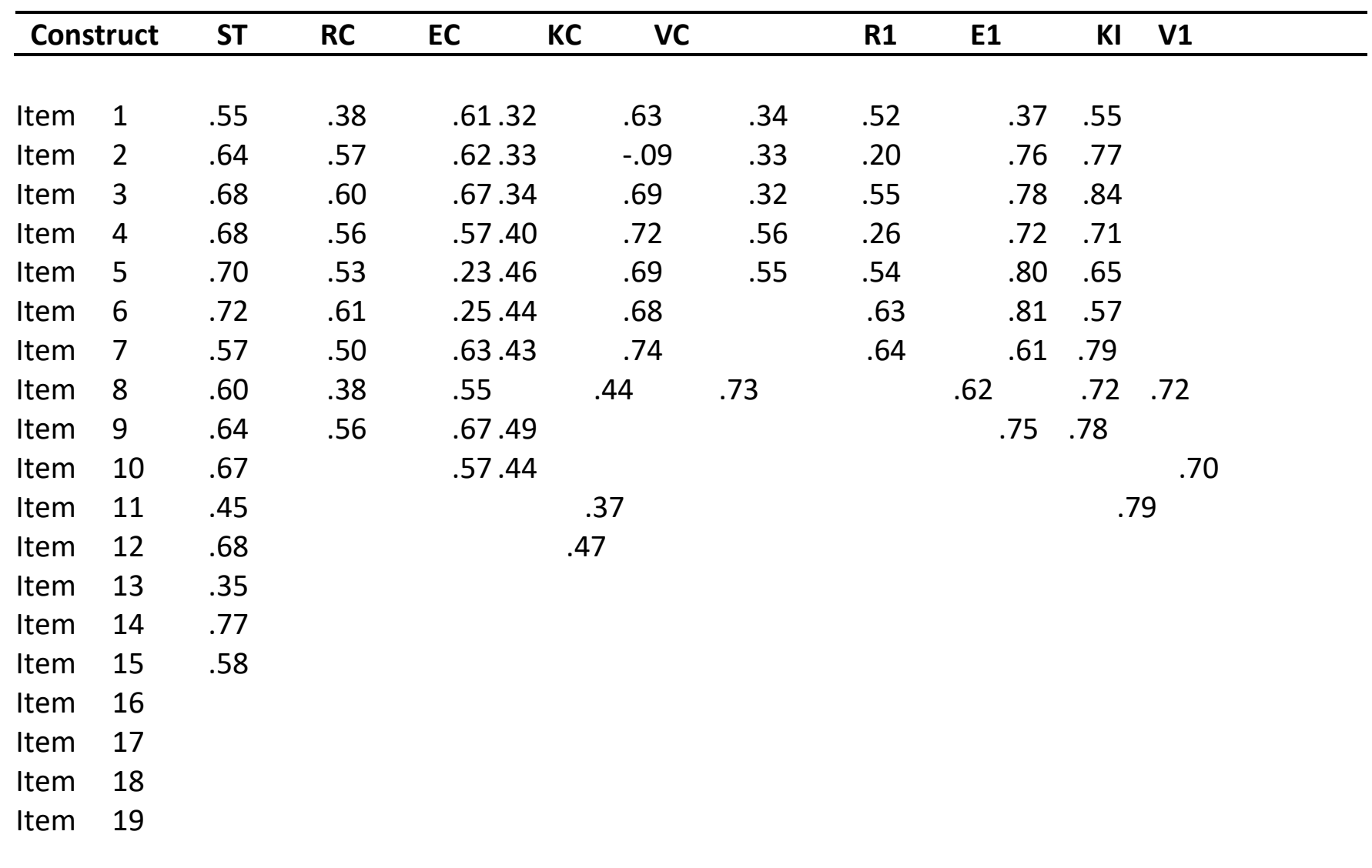

$\mathrm{ST}=$ Student' thinking, $\mathrm{RC}=$ Religious construct, $\mathrm{EC}=$ Education construct, $\mathrm{KC}=$ Knowledge construct, $\mathrm{VC}=$ Value construct, $\mathrm{RI}-$ Religious construct, $\mathrm{EI}=$ Education Influence, $\mathrm{KI}=$ Knowledge Influence, $\mathrm{VI}$ $=$ Value Influence.

This shows that these five items do not meet the construct criteria. Therefore, the item needs to be fixed or aborted. This analysis is a fundamental step in measuring the validity of the constructs used to build and validate the study of the Malay social traits to shape the value and morality of public university students. PTMEA Corr index will increase if misfitting of item is removed from measurement of item. 


\section{Discussion}

In overall, the findings of the research using the Rasch Measurement Model obtained the reliability of the item and the respondents were good. Construct influences value derives the lowest item reliability value and is considered weak, but still acceptable (Bond \& Fox 2007). Therefore, it is necessary to look back at the suitability of the item for this construct and the respondent who responds, whether items need to be repaired or aborted. While the isolation index for 69 items shows the difficulty of the item and the respondents' isolation index is based on the number of strata of ability in the respondent. The findings of the findings indicate that isolation index of items and respondents exceeding the value of 2 is considered good (Linacre 2005). It also shows the difference or isolation of respondents can measure the level of capability with the measured variables (Wright \& Master 1982; Bond \& Fox 2007).

The findings show that all items move in the same direction in interpreting the constructs to be measured through positive PTMEA. However, there is one item that has a negative PTMEA Corr value indicating that the item does not meet the criteria (Bond \& Fox 2007). Therefore, this item can be fixed or aborted. The item is from the core value construct. While there are four items that have PTMEA Corr values which are less than 0.30. This indicates the item also does not meet the criteria (Bond \& Fox 2007). These items should also be fixed or aborted. The items are from two constructs namely the education core constructs and the constructs of education influence.

\section{Conclusion}

The overall Winstep analysis finds that item reliability index and respondent reliability index is relatively high. Therefore, this study is reliable and valid for the first stage. Removal of items that are not compatible with the model should be considered for increased validity and reliability. While most of the items move in the same direction, but there are some items that do not contribute significantly to the measurement of the desired construct. This study is also important especially for researchers to be able to improve instrument, instrumentation, verification, reliability and selection of statistical methods to be used. It is very important to ensure that every item in a test is one-dimensional (items that measure the same trait), have a different and fair level of difficulty for all respondents who answer the instrument being constructed. The reliability of items and respondents should be taken seriously so that the instruments built with respondents who respond are consistent. Therefore, instruments can produce more meaningful measurements. The results of this study have contributed to a new discovery in the development of knowledge, namely, the construction of instruments that can measure and identify the Malay conscience that shaped manners and morals among students at the Public University.

\section{Acknowledgement}

This paper is based on the research project entitled: Hati Budi Melayu Membentuk Adab Dan Akhlak: Kajian Terhadap Mahasiswa Melayu Di Universiti Awam Malaysia. The authors would like to extend their gratitude to the Research Management and Innovation Centre (RMIC), Sultan Idris Education University (UPSI) and National University of Malaysia for the University Research Grants (code: 20170044-107-61) that helped fund the research. 
INTERNATIONAL JOURNAL OF ACADEMIC RESEARCH IN BUSINESS AND SOCIAL SCIENCES

Vol. 9, No. 7, July, 2019, E-ISSN: 2222-6990 (C) 2019 HRMARS

\section{References}

Baker, F. B., \& Kim, S. H. (2004). Item response theory: Parameter estimation techniques (2nd ed). New York: Marcel Dekker.

Bond, T. G. \& Fox, C. M. (2007). Applying the Rasch Model: Fundamental Measurement in the Human Sciences. (2nd ed.). Mahwah, New Jersey: Lawrence Erlbaum Associates.

Hj. Musa, H. (2008). Hati Budi Melayu: Pengukuhan Menghadapi Cabaran Abad ke-21. Serdang: Penerbit Universiti Putra Malaysia.

Lincare, J. W. (2002). What do infi $t$ and outfi $t$, mean-square and standardized mean?, Rasch Measurement Transaction 16(2): 878. http:www.rasch.org/rmt/rmt162fhtm. Jun, 2011.

Linacre, J. M. (2003). WINDTEPS Computer Program Version 3.48. Chicago www.winsteps.com. 9 September, 2010.

Linacre, J. M. (2005). Test validity, and Rasch measurement: Construct, content, etc. Rasch Measurement Transactions. http://www.rasch.org/rmt/rmt162fhtm.19 Julai, 2011.

Din, R., Ahmad, M., Kamarlzaman, F., Sidek, N. M., Karim, A. A., Johar, N. A., Ariffin, S. R. (2009). Kesahan dan kebolehpercayaan soal selidik gaya e- pembelajaran (eLSE) versi 8.1 menggunakan model pengukuran Rasch. Jurnal Pengukuran Kualiti dan Analisis, 5 (2), 15-27. 